\title{
LAMINE AHŞAP MALZEMENIN MEKANIK PERFORMANSLARI VE GÖRÜNTÜ ANALIZİ YÖNTEMIYLE EĞILME DIRENCI TESTINDE DEFORMASYONUN BELIRLENMESi
}

\author{
Mustafa ZOR ${ }^{1}$, Eser SÖZEN ${ }^{2 *}$, Timuçin BARDAK ${ }^{3}$ \\ ${ }^{1}$ Bülent Ecevit Üniversitesi, Çaycuma Meslek Yüksekokulu, Mobilya ve Dekorasyon Programı, Zonguldak \\ ${ }^{2}$ Bartın Üniversitesi, Orman Fakültesi, Orman Endüstri Mühendisliği Bölümü, Bartın \\ ${ }^{3}$ Bartın Üniversitesi, Bartın Meslek Yüksekokulu, Mobilya ve Dekorasyon Programı Bartın
}

\section{ÖZET}

Bu çalışmada; farklı tutkallarla lamine edilmiş sarıçam (Pinus sylvestris L.) ve göknar (Abies bornmülleriana Mattf.) odunlarının mekanik performansları belirlenmiş ve görüntü analizi yönteminin deformasyonların belirlenmesinde kullanılabilirliği, klasik yöntemle karşılaştırmalı olarak araştırılmıştır. Çalışma sonuçlarına göre, en yüksek eğilme direnci ve liflere paralel basınç direnci, polivinil asetat (PVAc) tutkalı ile lamine edilen sarıçam odunlarında, sırasıyla $99,16 \mathrm{~N} / \mathrm{mm}^{2}$ ve $42,56 \mathrm{~N} / \mathrm{mm}^{2}$ olarak belirlenmiştir. Sonuç olarak, yüksek direnç özellikleri istenen kullanım alanlarında göknar yerine sarıçamın tercih edilmesi önerilmektedir. Eğilme testleri sırasında oluşan deformasyonlar, Labview ${ }^{\mathrm{TM}}$ grafiksel programlama dili ile geliştirilen yazılım klasik yöntem ile karşılaştırılmış, iki yöntem ile elde edilen veriler literatür ile uyumludur.

Anahtar Kelimeler: Lamine ağaç malzeme, mekanik özellikler, görüntü analizi yöntemi, deformasyon.

\section{MECHANICAL PERFORMANCES OF LAMINATED WOOD AND DETERMINATION OF DEFORMATION IN THE BENDING TEST WITH THE AID OF IMAGE ANALYSIS METHOD}

\begin{abstract}
In this study, the mechanical performance of Scotch Pine (Pinus sylvestris L.) and Fir (Abies bornmülleriana Mattf.) wood laminated with different glues were performed and the availability of image analysis method for determining deformations in comparison with the conventional method was investigated. According to the results, the highest bending strength and compression strength parallel to grain in Scotch Pine wood laminated with polyvinyl acetate (PVAc) glue was determined $99.16 \mathrm{~N} / \mathrm{mm}^{2}$ and $42.56 \mathrm{~N} / \mathrm{mm}^{2}$, respectively. As a result, it is recommended to prefer scotch pine instead of fir in the usage areas in which the high strength properties desired. The deformations data obtained by using the software developed by Labview ${ }^{\mathrm{TM}}$ graphical programming compared with conventional method and the results of two methods are consistent with literature.
\end{abstract}

Keywords: Laminated wood material, mechanical properties, image analysis method, deformation.

*Corresponding author (Sorumlu Yazar)

Received (Geliş Tarihi) : 30.10 .2016

Accepted (Kabul Tarihi): 17.11.2016
Citiation (Atıf): Zor, M., Sozen, E., Bardak, T. Lamine Ahşap Malzemenin Mekanik Performanslari ve Görüntü Analizi Yöntemiyle Eğilme Direnci Testinde Deformasyonun Belirlenmesi Journal of Bartın Faculty of Forestry, 2016, 18 (2): 126i-136. 
Journal of Bartın Faculty of Forestry, 2016, 18 (2): 126-136

\section{GíRiş}

Dünya üzerinde en fazla fiyat artışına uğrayan malzemelerden biri olan kerestelerin orman kesiminde uygulanan kısıtlamalar, çevre kuruluşlarının oluşturduğu gibi nedenler dolayısıyla tedarik edilmesi her geçen gün daha da güçleşmektedir. Fiyatlardaki bu artış ve aynı zamanda ağaç konstrüksiyon malzemesi olarak kullanılacak boyutlarda kerestelerin bulunabilme güçlükleri bu malzemelerin değişik yollarla üretimini zorunlu kılmıştır. Bunun sonucunda daha küçük çaplı ve ekonomik anlamda pek fazla değeri olmayan ağaçların orman endüstrisine "mühendislik ürünü ağaç malzemeler" olarak kazandırılması sağlanmıştır (Mengeloğlu ve Kurt, 2004).

Teknolojik gelişmelere bağlı olarak yapılan çok yönlü araştırmalar, oduna yeni kullanım yerleri sağlayarak yeni endüstri dallarının doğmasına imkân vermiş ve kullanım alanlarını genişletmiştir. Buna paralel olarak estetik ve teknik yönden olumsuzluk sayılan ağaç kusurları atılarak kısa odun parçaları birleştirilmek suretiyle istenilen özelliklerde estetik malzemeler üretilebilmiştir. Bunun sonucunda da ara ve son ürünlerin üretilmesinde sentetik reçineli tutkalların önemi artmış, birçok kullanım yerinde çivi ve vida gibi mekanik bağlantı gereçleri yerini tutkallara bırakmıştır (Söğütlü ve Döngel, 2007).

Laminasyon işlerinde kullanılan odunun yapısı, yüzey pürüzlülüğü, pres basıncı, presleme süresi ve kullanılan tutkalın teknik özellikleri odunun yapışma mukavemeti üzerinde etkilidir. Farklı ağaç türlerinin aynı anda preslenmesi halinde pres basıncı yumuşak oduna göre belirlenmesi gerektiği bildirilmiştir (Bobat, 1994). Altınok ve Döngel (1999) ağaç türü olarak doğu kayını, sarıçam ve sapsız meşe odunlarını, tutkal olarak PVAc, Desmodur-VTKA ve Klebit 303 tutkalları ile yapıştırılarak elde ettikleri 3, 5 ve 7 katmanlı lamine elemanlarda en yüksek eğilme direncinin PVAc tutkalı ile yapıştırılan 5 katmanlı lamine elemanlarda elde edildiğini bildirmişlerdir.

Keskin ve Togay (2003) yaptıkları çalışmada, lamine edilmiş sarıçam (Pinus sylvestris L.) odununun bazı fiziksel ve mekanik özelliklerini incelemişlerdir. Bu maksatla sarıçam (Pinus sylvestris L.) odunundan polivinilasetat (PVAc-D4) tutkalı ile beş katmanlı olarak hazırlanan lamine edilmiş ağaç malzemeler kullanılmıştır. Hazırlanan deney örneklerinin; yoğunluk, çalışma miktarı, eğilme direnci, eğilmede elastiklik modülü, basınç direnci ve makaslama direnci araştırılmıştır. Sonuç olarak; lamine edilmiş sarıçam (Pinus sylvestris L.) ağaç malzemenin fiziksel ve mekanik özelliklerinin, bu ağaç türünü temsil eden masif ağaç malzemeye göre daha üstün olduğu belirlenmiştir.

Keskin (2004) sapsız meşe ve sarıçam kombinasyonu ile üretilen lamine ağaç malzemelerin teknolojik özellikleri ve en uygun kullanım yerlerinin belirlenmesi amacı ile yaptığı çalışma sonucunda, meşe ve çam kombinasyonu ile üretilmiş lamine ağaç malzemelerin hava kurusu yoğunluğunu $0,568 \mathrm{~g} / \mathrm{cm}^{3}$, eğilme direncini $107,5 \mathrm{~N} / \mathrm{mm}^{2}$, eğilmede elastiklik modülünü $10656,9 \mathrm{~N} / \mathrm{mm}^{2}$, basinç direncini $66,3 \mathrm{~N} / \mathrm{mm}^{2}$, makaslama direncini $9,9 \mathrm{~N} / \mathrm{mm}^{2}$ olarak bulunmuştur. Ayrıca; meşe ve sarıçam kombinasyonu ile üretilmiş lamine ağaç malzemelerin mobilya ve yapı malzemesi olarak kullanılmasını da önermektedir.

Görüntü yöntemlerinin temel öğesini oluşturan dijital görüntüler, genelde endüstriyel kameralar kullanılarak elde edilmektedir. Görüntüler, kameralardan bilgisayara aktarılarak kullanıcı tarafından geliştirilen veya bu amaçla hazırlanmış ticari yazılımlar kullanılarak analizleri yapılmaktadır. Bu işlemleri ayrıca eş-zamanlı (real-time) yapabilen sistemler de geliştirilmiştir (Güler vd., 2007). Görüntülerin bilgisayar ortamında işlenebilmesi için veri formatlarının bilgisayar ortamına uygun hale getirilmeleri gerekmektedir. Bu, sayısallaştırma (digitizing) adı verilen bir işlemle yapılır (Kılınç, 2009). 1 ve 0'lardan oluşan sayısal görüntü yapısı a[m,n], 2 boyutlu dünyadan elde edilen $\mathrm{a}(\mathrm{x}, \mathrm{y})$ fonksiyonundan örnekleme tekniği kullanılarak oluşturulur. Sayısal görüntü $M$ ve $N$ sayılarında satır ve sütunlardan oluşur ve satır ve sütunların kesiştiği her bölgeye piksel denir. O pikseldeki değer ise derinlik $(\mathrm{z}), \operatorname{renk}(\lambda)$ ve zamanın(t) bir fonksiyonudur (Çomak vd., 2011). Bir görüntü alanındaki ölçülen ilgi bölgelerinin her birinden elde edilen verilerin, çıktıları alınabilir, grafikler halinde sunulabilir ve/veya daha ileri analizler için bir veri tabanına dönüştürülebilir (Topal, 2008).

Mühendislik tasarımında yük-deformasyon ilişkisi büyük bir öneme sahiptir. Bu nedenle yük-deformasyon ölçümlerinde strain gauge, ekstensometre ve kırılgan kaplama metodu gibi yöntem ve araçlar geliştirilmiştir. Bu yöntemlerin kendine ait avantaj ve dezavantajları mevcuttur (Khan and Wang, 2001). Bilgisayar teknolojisindeki hızlı ilerlemeler dijital görüntü işleme ve analizi yöntemlerinin birçok alanda kullanılmasını sağlamıştır. Görüntü analizi yönteminin klasik ölçüm yöntemlerine göre birçok avantajı bulunmaktadır. Özellikle test sırasında örnekler üzerinde hiçbir temasa gerek duymadan sonuçlar elde edilebildiği için zorlu ortam (su altı, yüksek sıcaklık vb.) şartlarında kullanılabilir. Sistemin doğruluğu, kullanılan yazılıma, örnek büyüklüğüne ve örnek ile kamera arasındaki mesafenin doğru ayarlanmasına bağlıdır (Mikhail et al., 2001). 
Bu çalışmada, Polivinil asetat tutkalı (PVAc) ve Poliüretan tutkalı (PU) ile lamine edilmiş sarıçam (Pinus sylvestris L.) ve göknar (Abies bornmülleriana Mattf.) odunlarının eğilme ve basınç direnci değerleri deneysel olarak incelenmiştir. Ayrıca eğilme direnci sırasında klasik yöntem ile ölçülen deformasyonlar, son yıllarda mühendislik alanında sık kullanılan bir yöntem olan görüntü analizi yöntemiyle karşılaştırılmış ve bu yöntemin farklı alanlarda uygulanabilirliği ortaya konulmuştur.

\section{MATERYAL VE METOT}

\subsection{Materyal}

\subsubsection{Ağaç malzeme}

$\mathrm{Bu}$ çalışmada kullanılan göknar (Abies bornmülleriana Mattf.) ve sarıçam (Pinus sylvestris L.) odunları, Zonguldak ili Çaycuma ilçesinde bulunan Aydemir Kereste San. Tic. Ltd. işletmesinin üretim deposundan rasgele seçim (random selection) yöntemi ile temin edilmiştir. Ağaç malzemenin seçiminde kusursuz olmasına, liflerin düzgün, budaksız, reaksiyon odunu bulunmayan, mantar ve böcek zararına uğramamış olmasına dikkat edilmiştir. Deney örneklerinin hazırlanmasında kullanılacak ağaç malzemeler, sıcaklığ $20 \pm 2{ }^{\circ} \mathrm{C}$ ve bağıl nemi $\% 65 \pm 3$ olan iklimlendirme odasında değişmez ağırlığa ulaşıncaya kadar bekletilerek ağırlıklar $\pm 0,01$ duyarlı dijital teraziyle belirlenmiştir.

\subsubsection{Tutkal}

$\mathrm{Bu}$ çalışmada iki tip tutkal tercih edilmiştir. Bunlardan birincisi, laminasyon işlemlerinde, soğuk olarak uygulanması, kolay sürülmesi, çabuk sertleşmesi, kokusuz ve yanmaz olması gibi özellikleri nedeniyle yapı ve mobilya endüstrisinde yaygın olarak kullanılan, TS 3891'e uygun polivinilasetat (PVAc) tutkalıdır. Kullanılan bu tutkalın özellikleri üretici firma tarafindan yoğunluk 1,1 g/cm3, vizkositesi 160-200 cps, PH = 5,00, kül miktarı \% 3 olarak verilmiştir (Altınok, 1995). Bir diğer tutkal çeşidi olarak, yüksek yapışma dayanımı istenilen yerlerde, özellikle mobilya ve tekne imalatında kullanılan, suya ve neme karşı duyarlı, çözücü içermeyen, tek komponentli poliüretan esaslı aktif maddeli yapıştırıcı olan Poliuretan (PU) tutkalı seçilmiştir. Poliüretan tutkalı, ambalajı açıldıktan sonra doğrudan doğruya yüzeylerden emiciliği yüksek alana sürüldükten sonra, yapıştırma işlemi $20^{\circ} \mathrm{C}$ sıcaklık ve $\% 65$ bağıl nem şartlarında 30 dakika olarak verilmektedir. Vizkositesi $25^{\circ} \mathrm{C}^{\prime}$ de $3300-$ $4000 \mathrm{cps}$, yoğunluğu $20^{\circ} \mathrm{C}^{\prime}$ de $1.11 \pm 0.02 \mathrm{~g} / \mathrm{cm}^{3}$ olup soğuğa karşı dayanıklıdır (Klebchemie, 1997).

Ağaç malzemeden yapılan mobilya ve yapı elemanlarının ek yerlerinin birleştirilmesinde en etkili yöntemin yapıştırma olduğu, ek yerlerindeki açılmaların çoğunluğunun tutkallama işlemlerinde meydana gelen teknolojik hatalardan kaynaklandığı ve tutkalın, sürüldüğü yüzeyde heterojen dağılmasının kohezyon kuvvetlerini olumsuz yönde etkilediği bilinmektedir (Smardzewski, 2002). Bu nedenle, mevcut sentetik esaslı ahşap tutkallarının kullanım yeri özelliklerine göre seçiminin yapılması ve tutkalın uygulanma şartlarının doğru seçilmesi, birleştirmelerin dayanımına etki etmektedir. Dolayısı ile ahşap yapı endüstrisi uygulamalarında kullanılan tutkalların direnç özelliklerinin belirlenmesine ihtiyaç duyulmaktadır.

\subsection{Deney örneklerinin hazırlanması}

Hava kurusu rutubetinde ve 25x100x500 mm boyutlarındaki örnekler, 7x100x500 mm ölçülerine getirilmiş ve 3 tabakalı 20x500x500 $\pm 1 \mathrm{~mm}$ lamine levha taslağı oluşturulmuştur. Elde edilen levha taslağının boyutları Şekil 1 'de gösterilmiştir.

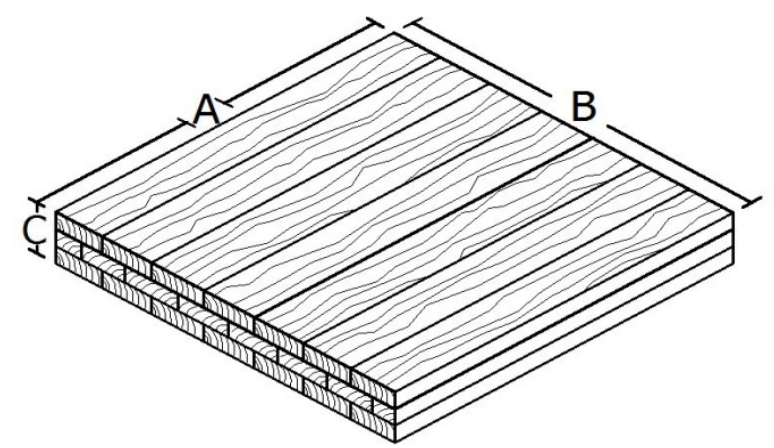

Şekil 1. Üretilen lamine levha taslağının ölçüleri (A:500 mm, B: 500 mm, C:20 mm). 
Lamine levha taslağı üretiminde yapıştırılacak yüzeylere, her iki tutkal türü için $160-180 \mathrm{~g} / \mathrm{m}^{2}$ olacak şekilde tutkal sürülmüştür. Deney örneklerine $20^{\circ} \mathrm{C}^{\prime} \mathrm{de} 1,5 \mathrm{~kg} / \mathrm{cm}^{2}$ basınç, 15 dakika boyunca uygulanmıştır. 2 tutkal türü, 2 ağaç malzeme kullanılarak 4 adet lamine levha taslağı üretilerek her bir test için 15 adet deney örneği hazırlanmıştır. Standartlara uygun olarak kesilen Sarıçam (Pinus sylvestris L.) ve Göknar (Abies bornmülleriana Mattf.) odunları ilgili tutkallar ile üç katlı olarak lamine edilmiştir.

\subsection{Metot}

\subsubsection{Yoğunluk}

Hava kurusu yoğunluk tayini için, TS 2472 (Anonim, 1972) standardına uygun olarak 20x20x30 mm ölçülerinde hazırlanan örnekler; $20 \pm 2^{\circ} \mathrm{C}$ sıcaklık ve \% $65 \pm 5$ bağıl nem şartlarında değişmez ağırlığa ulaşıncaya kadar kondisyonlanarak, rutubetleri hava kurusu (\%12) hale getirilmiştir. Bu durumda $\pm 0,01 \mathrm{~g}$ duyarlıklı analitik terazide tartılıp $\left(\mathrm{M}_{12}\right), \pm 0,01 \mathrm{~mm}$ duyarlıklı dijital kumpasla boyutları belirlendikten sonra, hacimleri $\left(\mathrm{V}_{12}\right)$ hesaplanarak, hava kurusu yoğunluklar $\left(\delta_{12}\right)$ aşağıdaki eşitlik (1) yardımıyla hesaplanmıştır.

$$
\delta 12=\frac{\mathrm{M} 12}{V 12} \mathrm{gr} / \mathrm{cm}^{3}
$$

\subsubsection{Statik eğilme deneyi}

Statik eğilme deneyleri TS 2474 (Anonim, 1976) standartlarında belirlenen esaslara göre üniversal test cihazında yapılmıştır. $20 \times 20 \times 300 \mathrm{~mm}$ boyutlarındaki numuneler deney işleminden önce $20{ }^{\circ} \mathrm{C}$ sıcaklık ve \% 65 bağıl neme sahip klimatize dolabında değişmez ağırlığa gelinceye kadar bekletilerek denge rutubetleri hava kurusu (\%12) hale getirilmiştir. Deneyler bilgisayar kontrollü üniversal test makinesinde gerçekleştirilmiştir. Yükleme başlığının hızı $5 \mathrm{~mm}$ /dakika sonra olacak şekilde ayarlanmış ve kırılma anındaki maksimum kuvvet ve deformasyonlar her örnek için ayrı ayrı kaydedilmiştir. Şekil 2'de statik eğilme direnci test düzeneği gösterilmiştir.

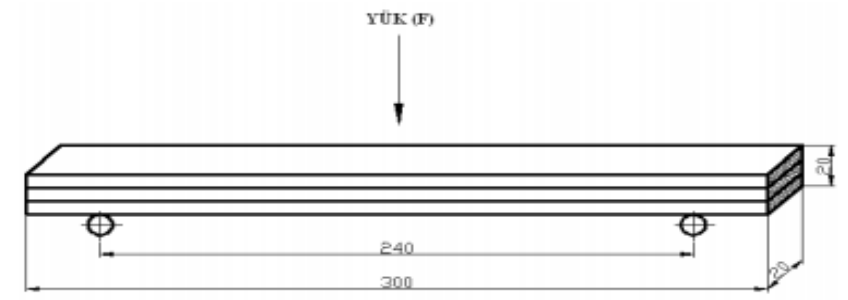

Şekil 2. Statik eğilme direnci test düzeneği (ölçüler mm’dir.)

\subsubsection{Liflere paralel yönde basınç deneyi}

Liflere paralel yönde basınç direnci testleri TS 2595 (Anonim, 1977) standardına uygun olarak üniversal test cihazında yapılmıştır. 20x20x30 mm ebatlarında hazırlanmış olan deney numuneleri $20^{\circ} \mathrm{C}$ ve $\% 65$ bağıl nem şartlarında denge rutubetine ulaşıncaya kadar klimatize edilerek \% 12 rutubete getirilmiştir. Numunelerin en kesitine tam ortadan ve yükleme hızı $5 \mathrm{~mm}$ /dakika olacak şekilde sabit bir yükleme hızı ayarlanmıştır. Kuvvet uygulaması, numune kırılıncaya kadar devam ettirilmiş ve kırılma anındaki maksimum kuvvet makinenin kadranından okunarak kaydedilmiştir. Çalışmada kullanılan sarıçam ve göknar ağaçlarına ait yoğunluklar, hava kurusu rutubette (\%12) ölçüldükten sonra testlere başlanmıştır. Testler, Bartın Üniversitesi, Odun Mekaniği ve Teknolojisi Laboratuvarında bulunan $1000 \mathrm{~kg}$ kapasiteli üniversal test makinasında gerçekleştirilmiştir. Liflere paralel yönde basınç direnci örneği Şekil 3'de gösterilmiştir. 


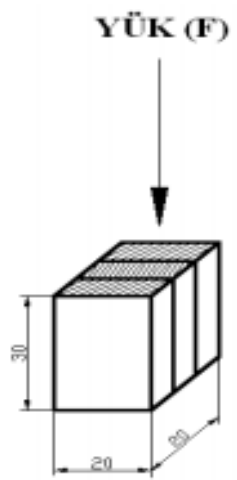

Şekil 3. Liflere paralel yönde basınç direnci test düzeneği (ölçüler mm’dir.).

\subsubsection{Görüntü analizi yöntemi}

Günümüzde modern üretim teknolojilerinin gelişmesi ile ölçümlerin yüksek hassasiyetli ve hızlı olması gerekmektedir. Klasik muayene yöntemleri modern üretimin ihtiyacını karşılayamamaktadır. Görüntü yöntemlerinin esnekliği ve kullanım kolaylığı büyük avantajlar sağlamaktadır. Bu yöntemler klasik yöntemlere göre daha hızlı, ekonomik ve güvenilirdir. Aynı zamanda bütün test prosedürü izlenip kayıt altına alınabilir. Böylelikle kayıtlar üzerinde geri dönüp tekrar inceleme yapma imkânı doğar (Güler vd., 2007).

Deformasyon ölçümü için 1628 x 1236 çözünürlüğe sahip saniyede 20 kare alabilen alan tarama kameras1 (Basler ace camera, acA1600-20gc) kullanılmıştır. Şekil 4'de eğilme testi ve dijital görüntü korelasyon yöntemleri ile deformasyon ölçümü için kurulan test düzeneği gösterilmiştir.

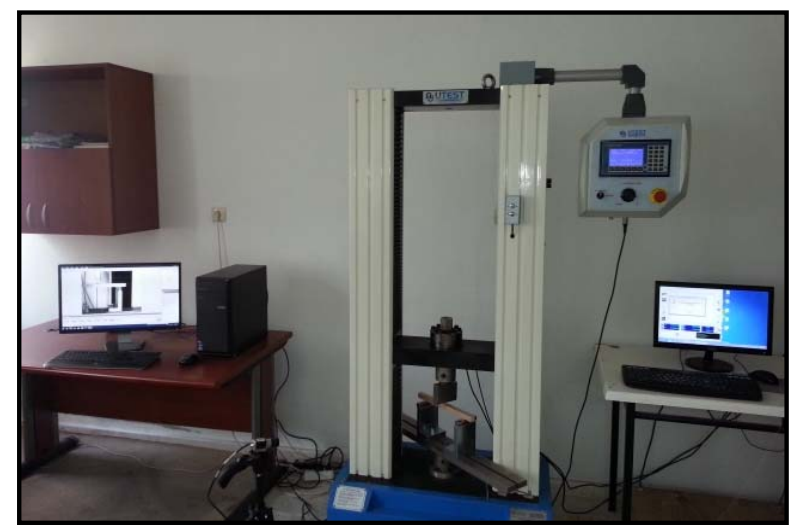

Şekil 4. Eğilme testi ve deformasyon ölçümü için kurulan test düzeneği

Deformasyon ölçümü için gerekli görüntüler Labview ${ }^{\mathrm{TM}}$ programının araçlarından biri olan 'NI Vision Builder for Automated Inspection' ile alınmış ve parçalarda belirli alanlar markalanmıştır. Şekil 5'de deformasyon ölçümü için alınan referans ve deforme alanlarına ait görüntüler verilmiştir.

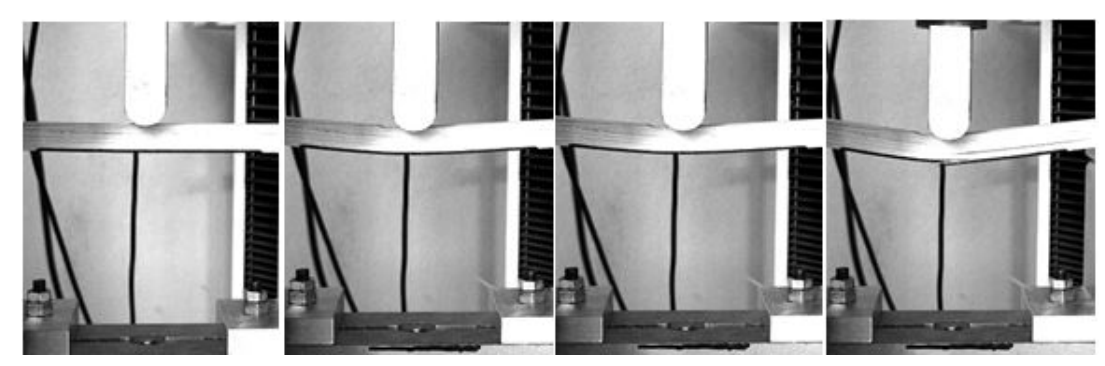

Şekil 5. Deformasyondan önce ve sonra alınan görüntüler

NI Vision Builder for Automated Inspection iki ana kısımdan oluşur. Bunlardan birincisi, geliştirilen programın algoritmasının yapılandırıldığı kodlama kısımdır, ikinci kısım ise kullanıcı ara yüzüdür. Şekil 6-a ve 6-b'de 
deformasyon analizi için algoritmanın geliştirildiği kodlama kısmı ve oluşturulan kullanıcı ara yüzü ve gösterilmiştir.

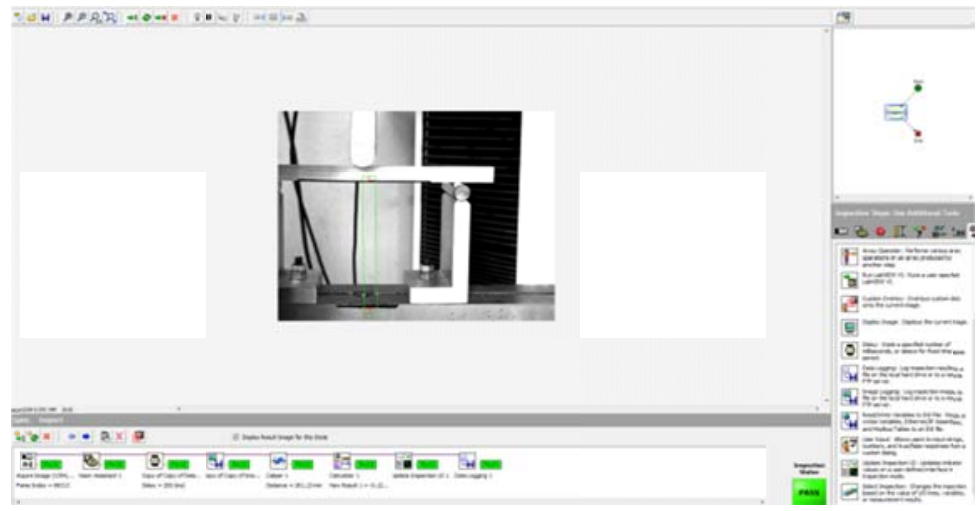

Şekil 6-a. Algoritmanın yapılandırıldığı kodlama kısmı

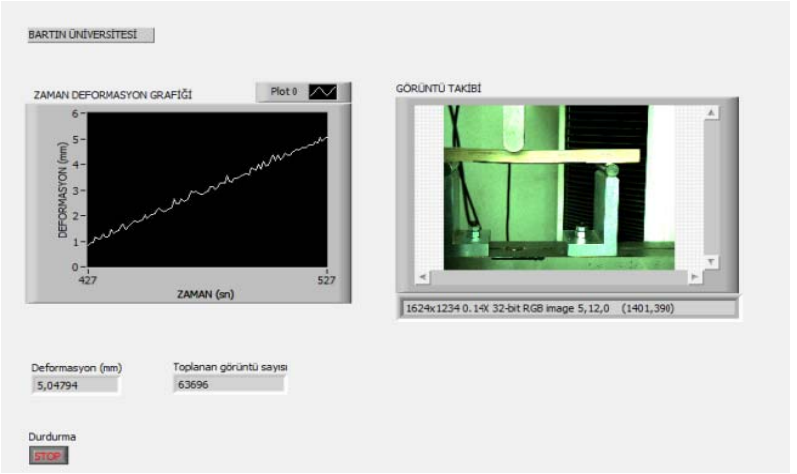

Şekil 6-b. Kullanıcı ara yüzü

NI Vision Builder for Automated Inspection programı ile deformasyon ölçümü için takip edilen adımlar gösterilmiştir. İşleme başlamadan önce saniyede alınacak görüntü üniversal test makinesine göre hesaplanmıştır.

\section{Görüntünün elde edilmesi:}

$\mathrm{Bu}$ işlemde 32 bit derinlikli RGB formatında renkli görüntüler sürekli olarak elde edilir.

\section{Görüntünün gerçek dünya ölçülerine göre kalibre edilmesi:}

Elde edilen görüntünün pikselleri gerçek dünya ölçüleri ile ilişkilendirilmiştir. Burada görüntüdeki piksel koordinatları $\mathrm{x}$ ve y yönlerinde ölçekleme yolu ile gerçek dünya koordinatlarına çevrilir. Bu işlemde görüntünün datalarında herhangi bir değişim oluşmaz . Şekil 7'de Kalibrasyon işlemi gösterilmiştir.
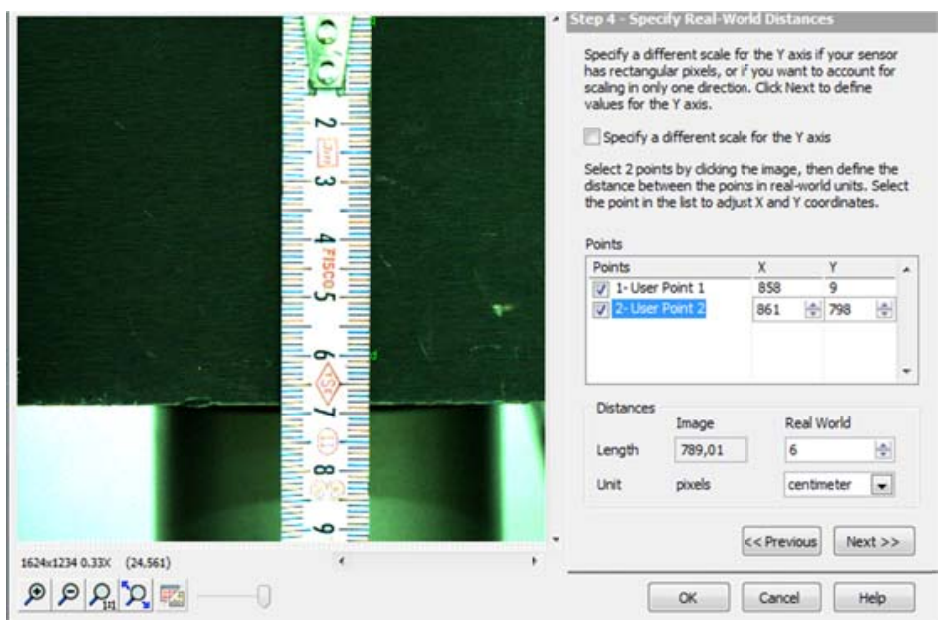

Şekil 7. Kalibrasyon işlemi. 


\section{Görüntülerin geliştirilmesi:}

Bu işlemde 32 bit derinlikli RGB formatında renkli görüntüler 8 bit derinlikli gri görüntülere dönüştürülür. RGB formatında kırmızı, yeşil ve mavi renk uzayları vardır. Bunların her biri 8 bit derinliklidir. Yazılımda görüntüden istenilen bir renk uzayı ayıklanarak 8 bit derinlik gri görüntüler elde edilir. Şekil 8'de 32 bit derinlikli RGB formatında renkli görüntü ve 8 bit derinlikli gri görüntü gösterilmiştir.

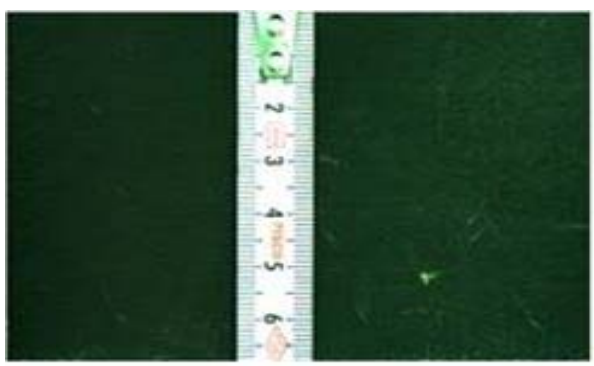

$-\mathrm{a}-$
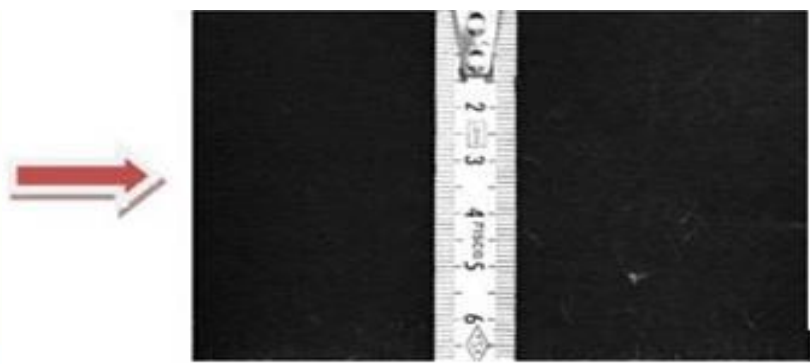

$-\mathrm{b}-$

Şekil 8.32 bit derinlikli RGB formatında renkli görüntü (a) ve 8 bit derinlikli gri görüntü (b).

\section{Görüntü almanın geciktirilmesi:}

Bu aşamada sürekli olarak görüntü elde ederken belirli bir süre bekletilerek bir sonraki görüntü alınır. Burada amaç üniversal test cihazının deformasyon ölçüm aralığı ile endüstriyel kameranın ölçümün aralığını senkronize etmektir.

\section{Görüntünün saklanmast:}

$\mathrm{Bu}$ aşamada elde edilen görüntüler gerektiğinde tekrar incelenmek üzere saklanır.

\section{Markalar arası mesafenin bulunması:}

$\mathrm{Bu}$ işlemde bir bölge içinde yer alan nesnenin iki kenarı arasındaki maksimum mesafe hesaplanır. Nesnenin kenarlarını karakterize eden keskin piksel değerleri vardır. 8 bit derinlikli gri görüntülerde 0-255 arasında değişen piksel değerleri bulunur. Yazılımda bir eşik değere ve kontrasta dayalı olarak kenar hatları oluşturur. Daha sonra kenar hatları aralarındaki mesafe hesaplanır. Şekil 9'da markalar arası mesafenin ölçülmesi şematik olarak gösterilmiştir.

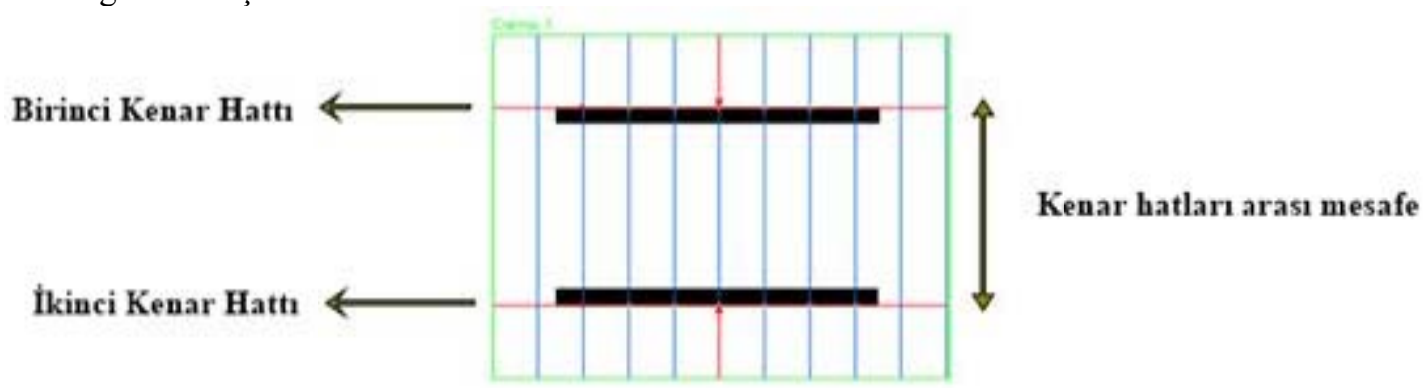

Şekil 9. Markalar arası mesafenin ölçülmesinin şematik gösterimi

\section{Deformasyonun hesaplanmast:}

Bir önceki adımda hesaplanan kenar hatları arası mesafeden yük altında malzemenin yer değiştirmesinden dolayı azalan kenar hatları arası mesafe çıkartılarak deformasyon sürekli olarak belirlenir. Şekil 10'da Labview programı ile deformasyonun hesaplanması gösterilmiştir.

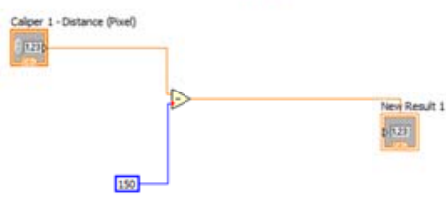

Şekil 10. Labview programı ile deformasyonun hesaplanması. 


\section{Kullanıcı ara yüzünün oluşturulması:}

$\mathrm{Bu}$ aşamada kullanıcının deney sırasında sonuçları takip edebilmesi ve kontroller gerçekleştirebilmesi için bir ara yüz oluşturulur.

\section{Verilerin toplanması ve saklanmast:}

$\mathrm{Bu}$ aşamada elde edilen deformasyon sonuçları üniversal test cihazının sonuçları ile karşılaştırmak için kaydedilir.

\section{Bulgular}

\subsection{Statik Eğilme Deneyi}

Statik eğilme direnci testlerinde, PVAc tutkalı ile elde edilen lamine ahşap malzemeler incelendiğinde, sarıçam odunu 99,75 N/mm² direnç ile göknar odununa göre $\% 40$ daha yüksek direnç göstermiştir. Poliüretan tutkallarında ise bu artış \%115 olarak belirlenmiştir. Ağaç türlerine ait yoğunluk ve statik eğilme direnci ortalama değerleri Tablo 1'de verilmiştir.

Tablo 1. Ağaç türlerine ait yoğunluk ortalamaları ve statik eğilme direnci değerleri

\begin{tabular}{|c|c|c|c|}
\hline $\begin{array}{l}\text { Ağaç } \\
\text { Türü }\end{array}$ & $\begin{array}{c}\text { Yoğunluk } \\
(\text { g/cm }\end{array}$ & $\begin{array}{l}\text { Tutkal } \\
\text { Türü }\end{array}$ & $\begin{array}{c}\text { Eğilme Direnci } \\
\left(\mathrm{N} / \mathrm{mm}^{2}\right)\end{array}$ \\
\hline \multirow{2}{*}{ Sarıçam } & \multirow{2}{*}{0,51} & PVAc & $99,75 \pm 8,3$ \\
\hline & & PU & $86,87 \pm 8,6$ \\
\hline \multirow{2}{*}{ Göknar } & \multirow{2}{*}{0,55} & PVAc & $71,20 \pm 10,2$ \\
\hline & & PU & $40,80 \pm 7,53$ \\
\hline
\end{tabular}

Ağaç ve tutkal türünün eğilme direnci üzerine etkisi istatistik anlamda önemli çıkmıştır $(\mathrm{F}=59,03 ; \mathrm{P}=0.000<0)$ .Faktörler arasındaki farklılığın önem derecesini belirlemek için yapılan Duncan testi sonuçları Tablo 2'de verilmiştir.

Tablo 2. Statik eğilme direncinde ağaç ve tutkal türüne ait Duncan testi sonuçları

\begin{tabular}{lcccc}
\hline \multicolumn{1}{c}{$\begin{array}{c}\text { Ağaç ve tutkal } \\
\text { Türü }\end{array}$} & \multicolumn{5}{c}{ A } & B & C & D \\
\hline Göknar +PU & 40,8286 & & & \\
\hline Göknar +PVAc & & 71,2857 \\
\hline Sarıçam +PU & & & 86,8000 & \\
\hline Sarıçam +PVAc & & & & 99,7571 \\
\hline
\end{tabular}

\subsection{Liflere paralel yönde basınç deneyi}

Liflere paralel basınç direnci testlerindeki farklılık oranı, eğilme direncine göre daha düşüktür. PVAc tutkalı ile elde edilen lamine sarıçam 42,56 N/mm² basınç direnci gösterirken, bu değer lamine göknar örneklerinde, lamine sarıçam örneklerine göre $\% 3$ azalarak $41,21 \mathrm{~N} / \mathrm{mm}^{2}$ olarak belirlenmiştir. Poliüretan tutkalında ise lamine göknar türleri, lamine sarıçam örneklerine oranla \%5,4 artış göstererek 42,31 N/mm² değerine ulaşmıştır. Ağaç ve tutkal türünün basınç direnci üzerine etkisi istatistiki anlamda önemsiz çıkmıştır. Örneklere ait liflere paralel basınç direnç değerleri Tablo 3 'te gösterilmiştir.

Tablo 3. Ağaç ve tutkal türüne ait liflere paralel basınç direnci değerleri

\begin{tabular}{ccc}
\hline Ăgaç Türü & Tutkal Türü & $\begin{array}{c}\text { Basınç Direnci } \\
\left(\mathbf{N} / \mathbf{m m}^{\mathbf{2}}\right)\end{array}$ \\
\hline \multirow{2}{*}{ Sarıçam } & PVAc & $42,56 \pm 4,2$ \\
& PU & $40,12 \pm 5,2$ \\
\hline \multirow{2}{*}{ Göknar } & PVAc & $41,27 \pm 5,0$ \\
& PU & $42,31 \pm 4,5$ \\
\hline
\end{tabular}




\subsection{Görüntü analizi ile deformasyonun belirlenmesi}

Üniversal test makinasında gerçekleştirilen statik eğilme direnci testleri sırasında, maksimum yüke karşılık gelen deformasyon değerleri makine tarafından ölçülürken, eş zamanlı olarak dijital kamera (Basler ace camera, acA1600-20gc) ile de ölçülmüştür. Kameradan alınan görüntüler Labview programlama dili ile sayısal verilere aktarılarak zamana bağlı deformasyon oluşumları belirlenmiştir. Elde edilen veriler, klasik yöntem ile karşılaştırıldığında ortalama \% 5,26 fark çıkmıştır. Elde edilen deformasyonlara ait veriler Tablo 4'te gösterilmiştir.

Tablo 4. Klasik yöntem ve görüntü analiz yöntemiyle elde edilen deformasyonların karşılaştırılması.

\begin{tabular}{cccc}
\hline Örnek & $\begin{array}{c}\text { Klasik Yöntem } \\
(\mathbf{m m})\end{array}$ & $\begin{array}{c}\text { Görüntü Analizi } \\
\text { Yöntemi }(\mathbf{m m})\end{array}$ & Fark (\%) \\
\hline Sarıçam-PVAc & 8,44 & 8,78 & 4,03 \\
Sarıçam-PU & 9,77 & 10,18 & 4,20 \\
Göknar- PVAc & 6,65 & 7,06 & 6,17 \\
Göknar- PU & 4,34 & 4,63 & 6,68 \\
\hline & & Ortalama & 5,26
\end{tabular}

İki yöntemin statik eğilme direnci testlerinde karşılaştırılması Şekil 11-12-13-14'de gösterilmiştir.

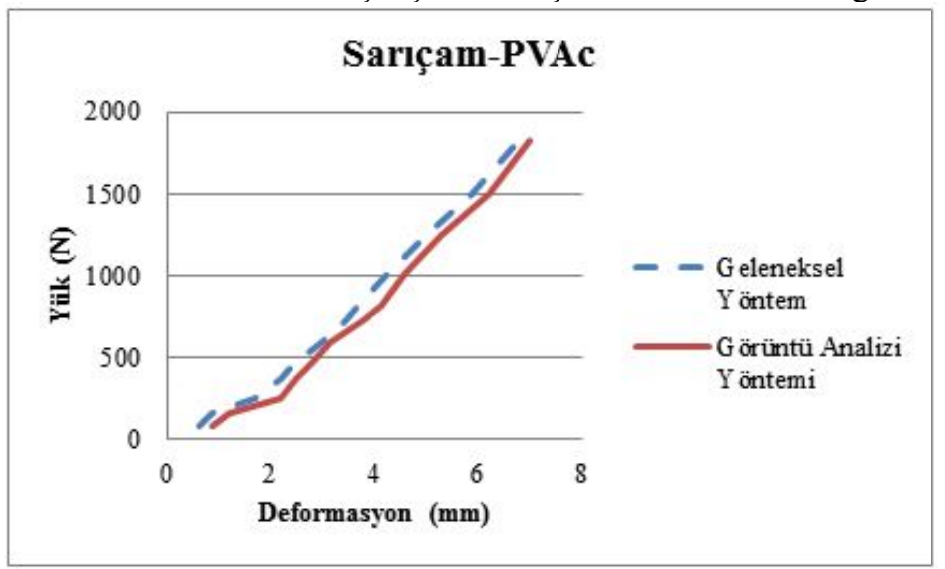

Şekil 11. Sarıçam türü PVAc tutkalı ile elde edilen yük-deformasyon grafiği

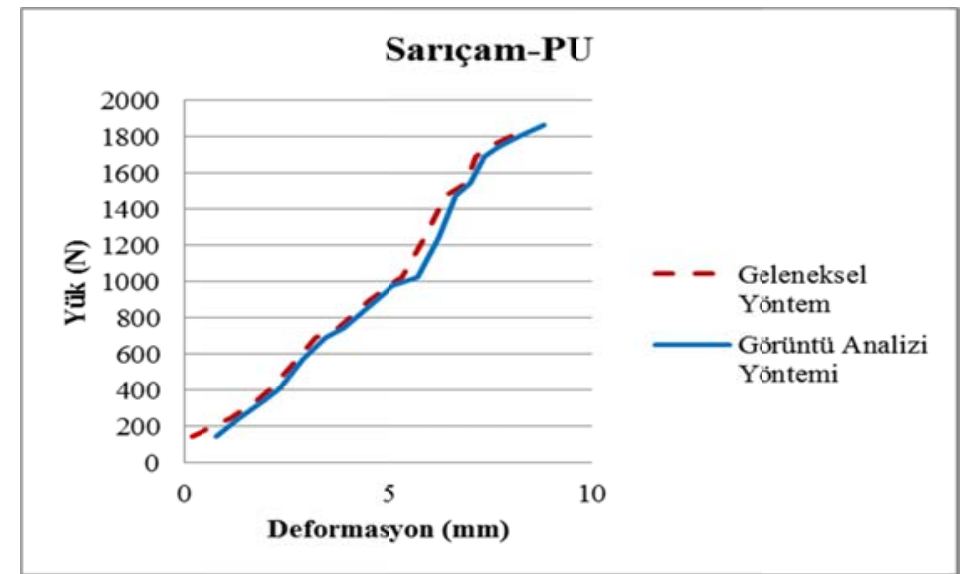

Şekil 12. Sarıçam türü PU tutkalı ile elde edilen yük-deformasyon grafiği 


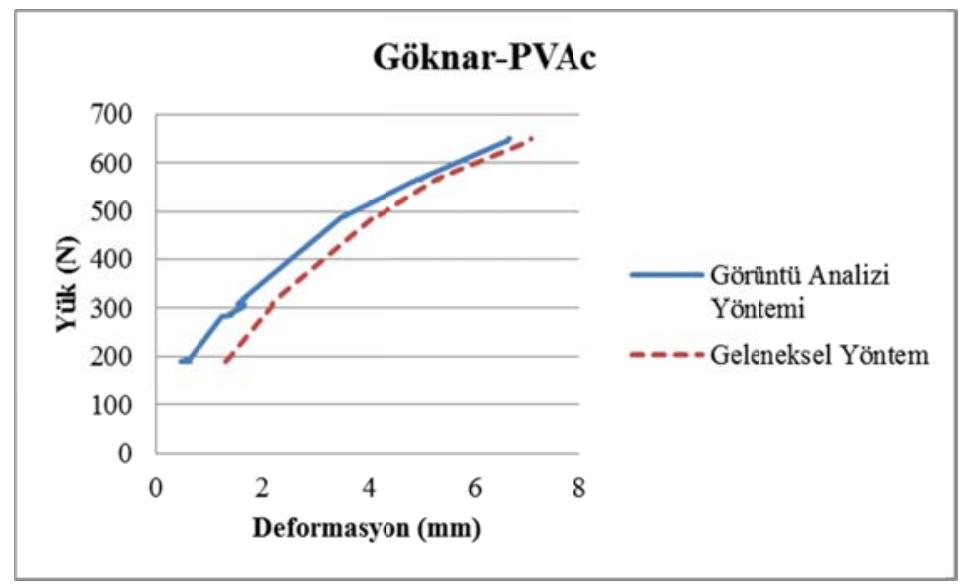

Şekil 13. Göknar türü PVAc tutkalı ile elde edilen yük-deformasyon grafiği

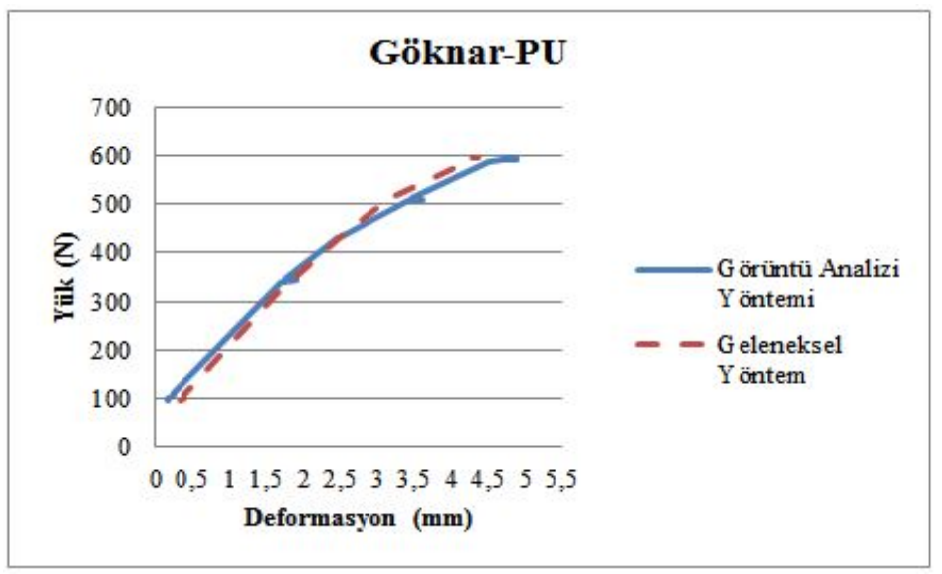

Şekil 14. Göknar türü PU tutkalı ile elde edilen yük-deformasyon grafiği

\section{SONUÇ VE ÖNERILER}

Çalışma sonuçlarına göre; PVAc tutkalı ile lamine edilmiş sarıçam türü ortalama $99,16 \mathrm{~N} / \mathrm{mm}^{2}$ ile en yüksek statik eğilme direnci değerini göstermiştir. Aynı test türü için en düşük değeri ise $40,80 \mathrm{~N} / \mathrm{mm}^{2}$ ile PU tutkalı ile lamine edilmiş göknar türü vermiştir. Liflere paralel basınç değerinde en yüksek değerler $42,56 \mathrm{~N} / \mathrm{mm}^{2}$ ile PVAc tutkalı ile lamine edilmiş sarıçam türünde, en düşük değerler ise PU tutkalı ile lamine edilmiş sarıçam örnekleri göstermiştir. Tutkal türlerine bakıldığında lamine edilen ağaç malzemeler arasında PVAc tutkalı mukavemet değeri olarak yüksek değerler göstermiştir. PVAc tutkalının ağaç malzemelerle kullanılma oranı oldukça yüksektir. Bu kullanım oranı, renksiz, ucuz ve direnç özellikleri nedeniyle özellikle mobilya endüstrisinde yoğunlaşmıştır. Bu çalışma ile PVAc tutkalının direnç özellikleri bakımından lamine ağaç malzemelerle kullanılabileceği belirlenmiştir. PVAc tutkalının mobilya yapımında sağladığı avantajlar yanında uygulandıktan sonra sıcaklık arttıkça yumuşama ile birlikte mekanik direncin azalması, $70{ }^{\circ} \mathrm{C}$ den sonra ise istenilen bağlayıcılığı gerektiği gibi sağlayamaması ve su dayanımının düşük olması gibi dezavantajları da vardır (Perçin vd., 2009). Bu nedenle yüksek sıcaklıklarda ve/veya nem oranı yüksek ortamlarda PVAc tutkallarının kullanılması uygun olmayacaktır.

İki yöntem arasındaki fark $(\% 5,26)$ yapılan çalışmalar (Islam, 2008; Wei, 2013) incelenıdiğinde kabul edilebilir seviyeler içerisindedir. LVDT (linear variable differential transformer) ve ekstensometre gibi klasik deformasyon ölçüm aletlerinde boyut sınırlandırılması vardır. Büyük ebatlı ahşap elamanların (Laminasyonlu ahşap kirişler) deformasyonlarının ölçülmesinde görüntü analiz yönteminden faydalanılabilir. Bununla birlikte ahşap malzemenin farklı yerlerinde (budaklı/budaksız vs.) meydana gelen deformasyonların ölçülmesi gerektiğinde, geliştirilecek doğru algoritmalar ile ölçümler yapılabilir.

\section{KAYNAKLAR}

o Altınok, M., 1995. Sandalye Tasarımında Gerilme Analizine Göre Mukavemet Elemanlarının Boyutlandırılması, Gazi Üniversitesi, Fen Bilimleri Enstitüsü, Doktora Tezi. 
o Altınok, M., Döngel, N. 1999. Laminasyonda Ağaç Türü, Tutkal Çeşidi ve Katman Sayısının Eğilme Direncine Etkileri. ZKÜ., Karabük Teknik Eğitim Fakültesi, Teknoloji Dergisi, (1-2), 225-235.

o Anonim, 1972. Odunda Fiziksel ve Mekanik Deneyler için Birim Hacim Ağırlığı Tayini, TS 2472. Türk Standartları Enstitüsü, Ankara.

o Anonim, 1976. Odunun Statik Eğilme Dayanımının Tayini, TS 2474. Türk Standartları Enstitüsü, Ankara.

o Anonim, 1977. Odunun Liflere Paralel Doğrultuda Basınç Dayanımı Tayini, TS 2595. Türk Standartları Enstitüsü, Ankara.

o Bobat, A. 1994. Emprenyeli Ağaç Malzemenin Kapalı Maden Ocaklarında ve Deniz İçinde Kullanımı ve Dayanma Süresi, KTÜ, Fen Bilimleri Enstitüsü, Doktora Tezi, Trabzon.

o Çomak, B., Beycioğlu, A., Başyiğit C. ve Kılınçarslan S. 2011. Beton Teknolojisinde Görüntü İşleme Tekniklerinin Kullanımı, 6th International Advanced Technologies Symposium, 220-227.

o Firm, P. (1997). Klebchemie, MG Becker Gmbh-Co. KG. D-76356 Weingarten, Germany.

o Güler, M., Sözen, Ş. ve Özen Ö. 2007. Görüntü Yöntemlerinin Beton Mikro Yapısının ve Çelik Birleşimlerin Deformasyon Davranışlarının Belirlenmesinde Uygulanması, Proje, Orta Doğu Teknik Üniversitesi, İnşaat Mühendisliği Bölümü.

o Islam, M., 2008. Developing Video Measurement of Strain for Polymers Using Labview, Master of Science, Bangladesh University of Engineering \& Technology, Mechanical Engineering.

o Keskin, H. 2004. Sapsız Meşe (Quercus petraea L.) ve Sarıçam (Pinus Sylvestris L.) Kombinasyonu İle Üretilmiş Lamine Ağaç Malzemelerin Bazı Teknolojik Özellikleri Ve Kullanım İmkânları, Gazi Üniversitesi, Fen Bilimleri Dergisi, 17(4):121-131.

o Keskin, H., Togay, A. 2003. Doğu Kayını ve Kara Kavak Kombinasyonu ile Üretilmiş Lamine Ağaç Malzemelerin Bazı Fiziksel ve Mekanik Özellikleri, SDÜ, Orman Fakültesi Dergisi. 2, 101-114.

o Khan, A.S. and Wang, X. W. 2001. Strain Measurements and Stress Analysis. Prentice Hall, New Jersey.

o Kılınç, İ. 2009. Çelik Malzemelerde Korozyon Oyuklarının Görüntü İşleme Yöntemiyle İncelenmesi, Sakarya Üniversitesi, Makina Mühendisliği Anabilim Dalı, Yüksek Lisans Tezi.

o Mengeloğlu, F. ve Kurt, R. 2004. Mühendislik Ürünü Ağaç Malzemeler Tabakalanmış Kaplama Kereste (TAK) ve Tabakalanmış Ağaç Malzeme (TAM). Kahramanmaraş Sütçü İmam Üniversitesi Fen ve Mühendislik Dergisi. 7(1), 39-44.

o Mikhail, E. M., McGlone J. C. and Bethel J. S. 2001. Introduction to modern photogrammetry, Wiley, New York.

o Perçin, O., Özbay, G. ve Ordu M., 2009. Farklı Tutkallarla Lamine Edilmiş Ahşap Malzemelerin Mekaniksel Özelliklerinin İncelenmesi, Dumlupınar Üniversitesi, Fen Bilimleri Enstitüsü Dergisi. 19, 109-120.

o Smardzewski, J. 2002. Technological Heterogeneity of Adhesive Bonds in Wood Joints, Wood Science and Technology. 36 (3), 213-227.

o Söğütlü, C., Döngel, N., 2007. Polivinilasetat (PVAc) ve poliüretan (PU) tutkalları ile yapıştırılmış bazı yerli ağaçlarda çekmede makaslama dirençleri. Politeknik Dergisi, 10(3).

o Topal, A. 2008. Agregaların Geometrik Özelliklerinin Belirlenmesine Yönelik Yeni Görüntü Analiz Yöntemleri Geliştirilmesi, Dokuz Eylül Üniversitesi, İnşaat Mühendisliği Bölümü, Yapı Anabilim Dalı, Doktora Tezi.

o Wei, K. S. 2013. Saravanan Karuppanan and Muhamad Ridzuan Bin Abdul Latif, Development of an Optical Strain Measurement Method Using Digital Image Correlation. Asian Journal of Scientific Research. 6, 411-422. 